\title{
O CORPO E O FEMININO ENQUANTO LUGARES DE SUBJETIVAÇÃO POSSÍVEL: O APORTE DAS ARTES VISUAIS
}

Alessandra Monachesi Ribeiro

\author{
Alessandra Monachesi \\ Ribeiro \\ Psicanalista, \\ pós-doutora em \\ Artes Visuais pela \\ ECA-USP e em \\ Arte e Linguagem \\ pela EHESS-Paris, \\ doutora em Teoria \\ Psicanalítica pelo \\ Programa de \\ Pós-graduação em \\ Teoria Psicanalítica \\ da UFRJ, com \\ estágio doutoral \\ no CRPM da \\ Université de Paris \\ VII e membro do \\ Ebep/SP, do Depto. \\ de Psicanálise do \\ Instituto Sedes \\ Sapientiae e da \\ Association de \\ Psychanalyse \\ Encore.
}

\begin{abstract}
RESUMO: Toma-se por base minha tese de doutorado, na qual busco perscrutar os lugares possíveis para a subjetividade em uma época em que a ausência de obra expandiu-se para todos os meandros da constituição subjetiva, criando-nos dificuldades em nos tornarmos sujeitos. Os lugares que busco mapear e discutir neste artigo, norteada principalmente pelo movimento de constituição de obra que é realizado no campo das artes visuais, e a partir da discussão feita por algumas artistas sobre tais lugares desde suas produções, são o corpo e o feminino.
\end{abstract}

Palavras-chave: Corpo, feminino, artes plásticas, arte e psicanálise.

\begin{abstract}
The body and the feminine as places for a possible subjectivity process: the visual arts contribution. This article is based on my PhD thesis, where I aimed to find possible places for subjectivity process in a time when the absence of work has expanded itself to all aspects of subjective constitution, creating to us difficulties on becoming subjects. These possible places I try to locate and discuss in this article, mainly based on the mouvement of constituting artwork that is still done within the contemporary art field, as well as guided by the discussion developed by some female artists regarding these places within their productions, are precisely the body and the feminine.
\end{abstract}

Keywords: Body, feminine, visual arts, art and psychoanalysis. 
$\mathrm{P}$ arto de minha tese de doutorado, na qual busco perscrutar os lugares possíveis para a subjetividade em uma época em que a ausência de obra expandiu-se para todos os meandros da constituição subjetiva, criando-nos dificuldades em nos tornarmos sujeitos. O movimento que torna a loucura ausência de obra, tão bem mapeado por Foucault $(1964,1972)$, se espalhou para outros campos da subjetividade, ou seja, o que ocorreu com a loucura — aqui entendida na exata acepção que lhe é atribuída no trânsito entre uma perspectiva trágica de enunciação de uma verdade e uma consciência crítica que termina por reduzi-la à doença mental que nada pode dizer de si — serve-nos como paradigma para um movimento dessubjetivante que, inaugurado pelo lugar que é dado à loucura, acomete cada vez mais aspectos das possibilidades de subjetivação. Assim, tal movimento dessubjetivante se dará com outras formas de existência psíquica, confinando-as no mesmo lugar de não-obra que a loucura passou a ocupar desde a idade clássica. Isso se dará, principalmente, pela disseminação da ideia de doença mental para muitos âmbitos da subjetividade humana, bem como, e em consequência disso, pela medicalização dessas subjetividades.

Se tal panorama das condições de subjetivação na contemporaneidade marcadas pela ausência de obra faz algum sentido, o que cabe interrogar a seguir é: haveria alguma obra possível — alguma subjetivação possível, consequentemente - nesse estado de ausência de obra? E, em caso afirmativo, o que diria essa obra existente acerca das condições para nossas subjetividades e até a respeito dessas subjetividades mesmas? Qual a subjetividade que se constitui no caldo da ausência de obra?

Por conseguinte, os lugares que busco mapear e discutir neste artigo, norteada principalmente pelo movimento de constituição de obra que é realizado no campo das artes visuais, e a partir da discussão feita por algumas artistas sobre tais lugares desde suas produções, são esses que se constituem no âmbito de sua ausência, no mesmo lugar da loucura como ausência de obra. Especificamente, e a partir do que o encontro com as artes visuais aporta para essa discussão, proponho esses lugares de subjetivação como o corpo e o feminino.

\section{AUSÊNCIÄ DE OBRA}

A ideia de obra, segundo Blanchot (1969) se apresenta como tendo uma ligação com o seu contrário: a ausência de obra é seu centro e o que lhe dá origem. A ausência de obra, ou a loucura, poderá ser tomada como o fora - da obra, da linguagem, da razão, como nos mostrará Foucault $(1964,1972)$ em seguida — necessário e interior à obra propriamente dita, mostrando-nos que uma obra não poderá ser concebida que não a partir de sua ausência. 
O lugar de ausência aparece como lugar de origem da obra e da fala: a obra não será possível que não nesse lugar de sua ausência. Esse paradoxo que faz da obra quase uma consequência da ausência de obra nos será rico por aquilo que ele indica a respeito das condições contemporâneas de subjetivação, que se apresentarão também nesse lugar em que se suporia sua ausência, particularmente no âmbito do corpo e do feminino, como veremos adiante.

Se retornamos a Foucault (1964), nos aperceberemos que sua aproximação da ideia de obra e de sua ausência torna a discussão arqueológica, à medida que ele fala de um movimento que rompe essa fluidez descrita por Blanchot (1969) entre a obra e sua ausência, tornando-as oposição entre lugares fixos, a partir do momento em que a loucura como ausência de obra se cristaliza como oposição à razão. Trata-se precisamente dessa ruptura, dessa perda de contato entre a obra e sua origem "desobrante" o que o interessa, além do contexto e dos jogos de poder e saber aí incluídos.

Assim, em seu História da loucura na Idade Clássica (FOUCAULT, 1972), quando trata de esclarecer a situação da loucura na modernidade e a maneira como essa situação se articula com o nascimento e o desenvolvimento do saber psiquiátrico, temos que a ideia de loucura como ausência de obra está ligada a uma construção que culmina no saber psiquiátrico entendendo-a como doença mental.

A ausência de obra é, portanto, como o outro nome da loucura, sendo a obra a consequência dessa ausência. Ela só pode se dar no campo da ausência, ou seja, nas bordas da possibilidade de subjetivação.

Se Foucault (1972) já apontava a loucura enquanto desrazão como aquilo que define o campo da razão por seu negativo, o que temos na loucura como ausência de obra é que esse campo - como foi outrora o campo da razão — depende daquilo que lhe é excluído para ganhar forma.

A estratégia da obra possível, assim como a da subjetividade possível, marcamse então a partir dessa delimitação que o “de fora” ou, se preferirmos, que o “da borda” delineia. Não é possível, consequentemente, pensar na possibilidade de obra e de subjetividade sem levar em consideração o seu ponto de origem na ausência de obra. Assim, partir da loucura para se chegar na arte contemporânea e à sua produção de obra, tanto quanto na subjetivação contemporânea que daí se depreende, adquire um novo sentido de que as possibilidades de obra não poderiam advir de outro lugar que não de sua ausência primeira.

Ou seja, do mesmo modo que a loucura como experiência trágica fica obscurecida pela consciência crítica pautada pelo conhecimento racional e científico, não deixando, entretanto, de existir, podemos pensar que a ausência de obra da qual ela fala também não deixa de dar notícias - mesmo desse lugar ilegítimo - da obra que ela produz. Então, a obra possível do lugar de sua ausência nos traz a subjetividade possível do lugar de seu assujeitamento. É nesse sentido que 
as obras produzidas pelas artes contemporâneas me trouxeram a condição de perscrutar o campo da obra que é feita no lugar de sua ausência.

Ao situar esse campo da ausência no lugar da loucura, tendo a propor que a possibilidade de obra/subjetivação na contemporaneidade advém desse lugar da loucura enquanto ausência de obra desde a Idade Clássica, ideia à qual as produções das artistas Nazareth Pacheco, Cindy Sherman e Marina Abramovic - cujos trabalhos estudei em profundidade em artigos anteriores e ao longo da tese de doutorado - vieram acrescentar forma e conteúdo. Esse campo que nomeio como campo de borda e de ausência de obra, a loucura, é aquilo que elas situam no corpo e no feminino.

\section{OS TEMAS DE BORDA: O CORPO E O FEMININO}

Retomando Foucault (1976), temos que o corpo e o feminino são lugares sobre os quais incidiu e incide diretamente o mandato da ausência de obra dos dispositivos do biopoder, pois o eixo central a articular a tecnologia disciplinar sobre o corpo individual e a tecnologia de regulamentação sobre as populações é a sexualidade.

O sexo tornado fala sobre sexo é normalizado a partir de uma série de discursos que buscam adestrá-lo. O corpo sexual inscreve a sexualidade no campo do biopoder, sendo intensificado ao extremo como objeto de saber. Corpos e prazeres intensificados como discurso passível de ser manipulado pelos dispositivos de saber/poder, eis o território a partir do qual o corpo feminino será sabido e agido, saturado de uma sexualidade aliada a seu papel de mãe e de reprodutora da espécie, modo possível de se pensar o lugar a ser ocupado por esse feminino a partir daí, tanto no campo das artes quanto no das subjetividades, como veremos a seguir.

Quero apenas destacar, antes de seguirmos adiante, que o corpo da mulher saturado de sexualidade é, segundo Foucault (1976), precisamente o que o constitui enquanto ameaça patológica e alvo da medicalização. Assim, o mesmo poder que se abate sobre a loucura como ausência de obra e doença mental recai sobre os corpos, e sobre o corpo feminino tornado doença na figura da mulher histérica. A mulher fica reduzida à figura da mãe e/ou à histeria — seu corolário - às custas do sacrifício de seu erotismo.

Vamos a Freud e àquilo que ele traz para a discussão sobre o corpo feminino no campo psicanalítico, paradoxalmente inserido e problematizador desse campo discursivo do poder disciplinar. 


\section{O CORPO FREUDIANO ENQUANTO CORPO INDÓCIL}

A materialidade e a corporeidade não passaram despercebidas a Freud que as apontava, tanto no texto a respeito do bloco mágico (1925[1924]/1996), como arquitetura possível do psíquico dependente de marcas e de lugares para tais marcas, quanto ao se referir, em “O ego e o id” (1923/1996) ao ego como projeção de uma superfície, estando aí considerada uma superfície corporal como o ponto de origem de uma precipitação que pode se entender como uma unidade e, mais ainda, no extenso trabalho que faz acerca das pulsões, especialmente em "Pulsões e seus destinos" (1915a/1996), que nada mais são do que a articulação entre psique e corpo, ou a exigência do corpo que dispara um movimento psíquico, dependendo esse último do que se movimenta como intensidade no primeiro. Ou seja, o corpo, em Freud, teve lugar proeminente para a construção de algum saber sobre o psíquico a partir de suas noções de inconsciente, de ego e de pulsão. Isso sem nem sequer mencionarmos a noção fundamental da sexualidade, na qual se apóia toda a construção metapsicológica freudiana e que tem, por sua vez, seu ponto de apoio e, também, suas consequências, naquilo que a psicanálise vai entender como corpo. A esse ponto retornarei mais adiante, restringindo-me, por ora, particularmente aos três primeiros conceitos que citei logo acima.

No que diz respeito ao inconsciente e sua articulação com a materialidade das marcas mnêmicas, podemos referir-nos ao modo como Freud (1925[1924]/1996) compreende a memória na dependência de uma materialidade do suporte para que ela se inscreva como representação. A memória não é factual para a psicanálise, mas construção permanente. A realidade psíquica se opõe à realidade material, conforme Freud afirma em “A interpretação dos sonhos” (1900/1996). O aparelho psíquico é aparelho de memória inventada, marcada pelos fantasmas e pela realização de desejo, permanentemente inscrito e transcrito. Isso indicará que a materialidade do suporte sobre o qual se depositam os traços mnêmicos não é um lugar estabelecido, mas uma corporeidade pulsante, dependente de seu próprio movimento.

Com isso, a ideia de que o inconsciente é, antes de qualquer coisa, uma instância corporal, será incrementada pela relação estabelecida por Freud entre o inconsciente e a pulsão, à qual tornarei adiante. Pois, se a memória em psicanálise vincula-se ao inconsciente e esse, por sua vez, através do pulsional relaciona-se ao corpo, temos aqui que a memória é - como o atesta o bloco mágico de Freud - corpo. Retomo, então, o texto de Freud sobre o inconsciente de 1915(b/1996), no qual ele vincula a representação inconsciente à marca de memória e, também, ao pulsional, duas formas de sua corporeidade.

Se a memória lança mão de um suporte para se estabelecer e criar uma marca psíquica, também no que diz respeito ao ego, Freud (1923/1996) estabelecerá 
uma vinculação com o corpo, ao afirmar o ego como projeção de uma superfície corporal. O ego, para ele, seria uma organização coerente de processos mentais responsável tanto pela consciência quanto pela descarga das excitações, a partir de seu acesso à motilidade. É de onde parte o recalque e, como consequência, a resistência.

A consciência, para Freud, é a superfície do aparelho mental, o primeiro ponto de um sistema a ser atingido pelas estimulações do mundo externo. Os traços mnêmicos são contidos em um sistema adjacente ao da percepção / consciência. Uma lembrança revivida é um traço mnêmico catexizado. O ego, que tem como núcleo a consciência e a percepção, é dominado e atravessado por várias forças: as que provêm do mundo externo, as pressões do recalcado inconsciente, as forças e intensidades pulsionais. O ego seria, portanto, a superfície do psíquico.

O corpo é um objeto destacado dos outros no campo perceptivo. Assim, se o núcleo do ego é a percepção/consciência, temos que seu núcleo é o corpo, quando Freud (1923/1996) afirma que o ego é corporal. Não apenas uma entidade de superfície que se alojaria na superfície do aparelho psíquico, mas também a projeção de uma superfície que é superfície corporal projetada psiquicamente como ego. Ele deriva das sensações corporais que se originam, principalmente, da superfície do corpo e, com isso, inscreve-se como sua encarnação psíquica.

Temos, então, que o inconsciente e o ego têm suas fundações no corpo, a partir da memória e da projeção da superfície corporal. Resta, para abordarmos a importância do corpo na constituição do psíquico em Freud, ver como também no campo do pulsional o mesmo guarda um lugar de base constituinte.

A pulsão brota no indivíduo como fenômeno físico e orgânico. Trata-se de um fenômeno fisiológico e de um processo energético-econômico. Ou seja, ela provém do corpo e coloca em movimento um processo que vai da necessidade ao acúmulo de energia que gera uma pressão no sentido da descarga que conduz à satisfação. Por sua vez, a pulsão é percebida pelo indivíduo como fenômeno psíquico — ideia, vontade, dor, medo, sensações - e o impele a agir. Nas palavras de Freud (1915a/1996):

“(...) um 'instinto’ nos aparecerá como sendo um conceito situado na fronteira entre o mental e o somático, como o representante psíquico dos estímulos que se originam dentro do organismo e alcançam a mente, como uma medida da exigência feita à mente no sentido de trabalhar em consequência de sua ligação com o corpo." (p.127)

A força constante da pulsão impulsiona ao movimento em um sentido, com um objetivo: ser satisfeita. E tal movimento que orienta a constituição e a circulação psíquica é disparado pelo acontecimento corporal. 
Parece-me interessante retomar Freud nesses três pontos em que ele vincula o psíquico a uma corporeidade - o psíquico como inconsciente e como aparelho de memória, o ego/eu como projeção de uma superfície corporal, e o pulsional como medida do psíquico paga às intensidades do corpo — não apenas para nos relembrar que o corpo está mais imbricado com o campo psicanalítico e com a própria psicanálise, quer como processo, quer como metapsicologia, do que costumamos considerar mas, também, para tecermos algumas considerações a respeito de como se articula essa imbricação.

É importante considerar, entretanto, o corpo de que estou falando. E aqui retomo a noção de sexualidade, tão cara à psicanálise.

A sexualidade humana é, como se comprova na leitura dos "Três ensaios para uma teoria da sexualidade" (FREUD, 1905/1996), aberrante em relação à função biológica da reprodução. Ela é infantil, perversa polimorfa, marcada pela pulsão e seus movimentos, a partir do princípio do prazer, no sentido da satisfação e da descarga.

O sexual e a sexualidade em psicanálise recuperam, portanto, a ideia de um corpo erótico, marcado pelo movimento das intensidades pulsionais e do desejo, circulado e circunscrito pelo desejo do outro, pela fala e pela história, investido, configurado por zonas erógenas, pelos modos, meios e históricos das experiências de satisfação. Ou seja, é um corpo tão dependente do outro para sua existência como suporte, em si, de que possa haver algo como um eu e um outro. É o corpo da percepção e da memória que, imbricadas, constroem algo como uma percepção e uma memória. Pois não se trata de um corpo organismo, mas de um corpo pulsional, intensivo, um corpo que também se faz enquanto corpo conforme percebe, marca e cria memória.

O corpo sexual freudiano é um corpo marcado pelo erotismo, pela pulsionalidade, pelo desejo e pela história. Trata-se de um corpo indócil, ou de um corpo que simultaneamente se assujeita e se rebela em relação à docilização que recai sobre ele. E a história desse corpo constituído em subjetividade é precisamente a história desses assujeitamentos e dessas resistências que têm como palco o corpo, assim como seus desdobramentos em termos de trabalho e constituição de psiquismo.

O que as artistas com as quais dialogo ao longo desse texto trazem para esse corpo freudiano - em especial no que diz respeito aos trabalhos de Nazareth Pacheco e de Marina Abramovic — é, exatamente, o modo como essa resistência ou rebelião pode se dar, ou seja, através da reinserção de sua materialidade corpórea na obra, da recolocação em cena de tudo aquilo do corporal que fora negado para que o mesmo se tornasse apresentável. Uma manobra contra sua assepsia. 
O sangue, a carne, aludidos nas instalações, a concretude do corpo presente na performance, tudo isso reapresenta o corpo pulsional e erótico - mesmo quando vai ser destituído até mesmo de seu erotismo e de sua vinculação à sexualidade a fim de enfatizar sua radicalidade enquanto corpo mortal, como acontece ao longo dos trabalhos de Marina — problematizando a calmaria de sua tácita aceitação enquanto corpo descorporificado naquilo que fora sua representação artística antes, ou naquilo que, no domínio das subjetividades, apresenta-se como corpo apaziguado por meio do apaziguamento do olhar, negação de seu potencial de convulsão relembrado pela histeria e tão bem considerado pela obra freudiana.

Ele é, ainda, um corpo marcado pela diferença e pela sexuação enquanto materialidades que o compõem e que dele demandam trabalho psíquico a fim de se configurarem enquanto condição de subjetivação. O corpo tomado por Freud, então, em sua materialidade imbricada em sua eroticidade, não pode prescindir de uma nem de outra para produzir psiquismo, o que significa que os contornos desse corpo implicarão em consequências naquilo que ele será enquanto marca psíquica.

Dessa forma, que haja um corpo de mulher, ou um corpo feminino, parece tratar-se de uma marca nada desprezível para o que se constituirá tanto quanto corpo erótico quanto como inscrição psíquica de tal corpo e de tal feminilidade. E temos que, para a psicanálise, a principal marca desse corpo feminino — ou sua marca inaugural — é sua inscrição psíquica enquanto histeria. É a mulher histérica do corpo feminino, marcado eroticamente pelos movimentos e convulsões que a levam à conversão, a inauguradora do campo conceitual e discursivo da psicanálise, ou seja, a mulher e o corpo feminino nesse lugar da histeria — patologização de sua condição subjetiva.

\section{O FEMININO PSICANALİTICO ENQUANTO TRANSBORDAMENTO DA LÓGICA FÁLICA E DA IDEIA DE ORIGEM}

Assim, se ser mulher é ser uma histérica, lá estão as primeiras histéricas de Freud que não nos deixam mentir. Se, para Freud, o organizador do psiquismo é a passagem pelo complexo de Édipo e o confronto com a castração, há diferenças na maneira como tal processo atinge homens e mulheres, bem como no lugar que teria para uns e outras. Enquanto o menino tem por objeto de amor a mãe e por rival o pai, numa acepção simples, unidirecional e positiva daquilo que se encontra proposto desde 1905 (1996), com os Três ensaios sobre a teoria da sexualidade, - em oposição ao Édipo completo de que falará em "O ego e o id” (1923/1996) - para a menina, cujo primeiro objeto de amor também é a mãe, haverá a necessidade de um percurso mais complexo que lhe permita mudar de 
objeto — investindo assim no pai — do mesmo modo que tem que mudar de zona erógena do clitóris, seu correspondente ao pênis do menino, para a vagina. É o que Freud constatará na década de 1920, com seus textos sobre o tema.

Assim, trata-se de um verdadeiro clichê psicanalítico que a mulher tenha dificuldade em se descobrir enquanto tal. Desde Freud e seus Estudos sobre a histeria (1893-95/1996) tomamos conhecimento dessa maneira típica pela qual as mulheres guardam a ilusão de serem portadoras de um falo posto em equivalência com o pênis em seus corpos convertidos em sintomas. Evidentemente, o sintoma estando a serviço da manutenção dessa ilusão fálica na qual nenhum lugar será destinado à falta. De forma que, segundo Freud (1931/1996, 1933/1996), descobrir-se como mulher, um ser sexuado, barrado e também em falta passa por atravessar o complexo de Édipo tanto quanto pela aceitação da castração, dois processos bastante falhos no que diz respeito às mulheres diferenciadas dos homens após sua equivalência nesse sentido apresentada nos Três ensaios sobre a teoria da sexualidade (1905/1996). Daí que, ao se descobrirem já castradas, elas não terão nenhuma razão tão forte quanto os homens para renunciar a seus prazeres pré-genitais e a seu primeiro objeto - a mãe, fazendo de sua escolha do pai e de seu acesso ao conhecimento do prazer vaginal pontos de chegada, não de partida como para os homens. Para as mulheres fica reservado, nesse momento, o lugar de incompletude frente ao homem tanto quanto face às possibilidades de subjetivação que demandam um acesso à via simbólica, encontrado apenas pela travessia do Édipo, o que não será evidente em seu caso uma vez que seu processo a envia para o Édipo, mas não para fora dele. Quer pelo deslocamento ter um pênis - ter um bebê, quer por meio da permanência nesse lugar em que se pode ainda acreditar que o pênis existe por meio do sintoma neurótico, quer pela opção homossexual, Freud dá às mulheres soluções falhas que retornam sempre à manutenção dessa posição fálica e narcísica através da qual buscam uma restauração do que foi perdido no momento em que elas se descobriram castradas. É por essa razão que a mulher freudiana (1914b/1996), menos motivada para sair de uma posição narcísica, se ocupa mais de ser amada do que de amar, buscando a passividade de existir enquanto objeto do olhar e da ação dos homens.

Constatamos aqui que a teoria freudiana repete nela mesma as contradições e os impasses ligados às mulheres e à denegação em conceber um feminino que indique uma existência fora da referência ao falo, fora da linguagem e do simbólico, ligado ao que não pode ser nomeado. A teoria freudiana é tão fálica quanto a descrição que ela faz dessa organização psíquica, tomando sempre o falo como o ponto de partida e o ground zero de toda possibilidade de subjetivação humana. Não haveria nada além? 
Aqui, também, os trabalhos das artistas previamente citadas - especialmente as produções de Cindy Sherman, mas não apenas elas — contribuem para problematizar o feminino freudiano, do mesmo modo que problematizaram o corpo freudiano, como acabo de abordar antes, ao trazerem a discussão acerca desse feminino para além daquilo que fica subsumido à lógica fálica e ao âmbito do que pode ser contornado pela castração e pela maneira como a mulher se articula com a mesma.

O feminino da mascarada revela a falácia da lógica das máscaras, feminino e masculino articulados a partir do falo desconstruindo-se e desconstruindo-o ao mostrar que o desvelamento, assim como a própria ideia do véu, conduzem ao engodo de pautar-se em uma ideia de origem e de verdade última que os trabalhos de Cindy Sherman tensionam até o limite de sua dissolução. Véus, artifícios e estratégias mostrados reintroduzem o feminino enquanto possibilidade outra que escapa à ordem do desvelamento e da verdade, impasse frente ao qual a psicanálise não ficará imune, forçada que será a considerar o feminino também em relação a essa brecha que o põe fora daquilo que o saber psicanalítico propôs enquanto modo de constituição psíquica alicerçada no campo do representável e do simbólico. Foi necessário surgir Lacan para que essa aproximação à mulher e ao feminino sempre fragilmente ordenados pela organização fálica fosse posta em questão.

Será Lacan quem se perguntará se a mediação fálica dará conta de todo o campo pulsional em uma mulher. Deslocando-se do campo do sexo para o campo do gozo, se indagará acerca de um gozo feminino, considerando que existe, para a mulher, uma divisão entre ser "toda fálica" e "não toda fálica”.

A lógica da castração não rege todo o campo do gozo, resta uma parte que é fora do simbólico. A mulher, que não existe para Lacan, nada mais é do que um dos nomes desse gozo. Ela é, então, o outro nome do real, da borda, do Outro. Falar sobre a mulher é falar a respeito disso tudo. É como falar do corpo, daí sua aproximação ao feminino.

Descobrir-se enquanto mulher não é necessariamente encontrar uma referência de si em relação aos homens, nem ao masculino, nem mesmo ao feminino. Lacan, em seu seminário 20, intitulado “Mais, ainda” (1972-1973/1985), refere-se à mulher como o sujeito que traz a alteridade radical, uma vez que ela é toda fálica e não toda fálica. Isso quer dizer que a mulher não pode ser reduzida nem encerrada em uma referência ao masculino, nem ao falo. Algo escapa, criando todo um outro continente desconhecido do qual não podemos nos aproximar a não ser pela via do simbólico, a qual apela necessariamente à palavra para tornar-se símbolo. Assim, são aproximações mancas essas que se dão pelo meio da linguagem na qual esse não toda fálica não pode ser totalmente circunscrito. 
Prosseguirei essa discussão através dos exemplos trazidos pelos trabalhos das artistas que nos acompanharam ao longo desse artigo mas, neste ponto, quero apenas assinalar que há um interesse nesse tema que permite pensar psicanaliticamente sobre o mundo contemporâneo a partir do feminino, como fez Joel Birman (1999, 2006). Ele nos apresenta a ideia de que, se a distinção entre os sexos se constrói a partir do referencial fálico, pensar sobre a feminilidade é deslocar-se para o lado de fora do mesmo e de suas construções, colocando-nos em outro registro quanto à sexualidade. Haveria, portanto, uma via de existência pelo feminino.

\section{CORPO E FEMININO NO ÂMBITO DAS ARTES VISUAIS}

A mulher foi, durante séculos, um dos objetos privilegiados do olhar e da ação dos artistas, a passividade de ser vista como pintura ou escultura enquanto signo de beleza ao passo que aos artistas — quase sempre homens — seria reservada a atividade de pintá-las ou esculpi-las. Essa divisão tão marcada começa a ser perturbada apenas após os movimentos vanguardistas, quando a beleza foi posta em questão enquanto objetivo principal do trabalho artístico por meio da dobra da arte sobre si mesma. É com as vanguardas que a arte se distancia de seu aspecto representacional sob cuja rubrica ela havia sido feita com o fim de ilustrar os valores maiores de cada cultura — sejam eles religiosos ou seculares — para se voltar para as discussões sobre a arte propriamente dita, inclusive sobre sua fatura: as cores, a forma, a perspectiva, a representação, tudo isso sendo posto em discussão tanto quanto desconstruído.

É com Gustave Courbet e seu Origine du monde (1866) que a mulher — ou o corpo feminino - interroga seu espectador pela primeira vez de maneira chocante. As mulheres tão belas quanto adequadas a servirem como objeto do olhar apaziguador, no mesmo sentido em que Lacan (1964/1998) fala do quadro que faz com que o olhar se pacifique e seja deposto, mudam de posição e, depois disso, olham as pessoas de frente. A Olympia de Édouard Manet, de 1863-65, serve como referência a propósito de tal mudança, a mulher nua confrontando por seu olhar duro e por seu rosto vulgar aqueles que ousam se postar em frente ao quadro, desconstrução de todos os nus anteriores nos quais a mulher estava sempre passivamente aberta a ser contemplada. A Olympia de Manet olha seu espectador, ela olha fora do quadro e, dessa maneira, ela se faz ser olhada enquanto pintura, não como uma representação das mulheres. Mais ainda, ela faz referência à sua sexualidade, ela nos olha e nos confronta com seu sexo, nos desafiando enquanto toca seu sexo, reenviando-nos ao quadro de Courbet e à maneira por meio da qual será o sexo da mulher o que nos confrontará. 
Dupla mudança: a mulher vista agora olha e, também, a representação da mulher se desconstrói ao se desvelar quadro, o que coloca uma questão à representação na arte e uma outra ao objeto mulher enquanto objeto do olhar. Uma mudança tão notável quanto a que terá lugar no momento em que as mulheres se colocarão do lado de fora das telas a fim de fazer suas próprias obras.

Mas retornando ainda a Courbet, o que ele faz por meio de seu Origine du monde é se aproximar tanto de seus temas que a distinção entre ver e ser visto será praticamente eliminada, levando consigo a oposição entre o homem que olha e a mulher enquanto objeto desse olhar. Em frente à Origine du monde, é sobretudo o quadro que nos olha em retorno ao nosso olhar, embaraçando as distinções. Até aqui, nada de diferente daquilo que foi dito a respeito do desafio feito por Olympia alguns anos antes. E, no entanto, no quadro de Courbet que propus como obra fundadora de uma questão trazida pelo feminino aos domínios artísticos, é o sexo da mulher que nos olha. Será necessário, também no campo das artes, cerca de 50 anos até que Marcel Duchamp recoloque em jogo a questão posta por Courbet a propósito e a partir do feminino: o feminino, o que é fora do jogo olhar/ser olhado, da pintura como representação e da representação como apenas pintura?

Mais do que à Fountain de 1917 de Marcel Duchamp, em que um mictório feito para receber passivamente os líquidos masculinos é invertido ao se tornar uma fonte, um dispositivo ativo de projeção que, ao mesmo tempo, guarda a significação popular linguística de sexo da mulher, trazendo novamente o tema das misturas e das desconstruções no que tange às diferenças sexuais, faço referência a seu último trabalho, os Étant donnés de 1946-66, obra póstuma na qual o espectador olha através de buracos feitos em uma parede para ali descobrir um manequim feminino sem cabeça, deitado sobre um tapete de grama artificial, ao fundo de uma paisagem campestre, tendo uma lâmpada acesa em uma das mãos e as pernas abertas a mostrar seu sexo (ou seu não sexo, ali no lugar onde se suporia encontrar um). No fim, reencontramos quase a mesma cena do quadro de Courbet à exceção do sexo que não é mais mostrado em detalhes. Um sexo que fazia alusão ao buraco torna-se agora um sexo sem buraco que faz alusão ao sexo. Uma negação, talvez? Eis o que Marcadé (1995) diz a respeito de Fountain e que pode bem servir para o Étant donnés:

\footnotetext{
“Fountain se pretende deliberadamente como um atentado ao 'bom gosto' da arte, ao seu poder de idealização. Há, expressa nessa obra, a vontade de fazer descerem as coisas da arte das alturas etéreas onde elas mais gostam de estar. Por mais provocadora que seja, a abordagem de Duchamp não deixa de ser genealógica — e, ao mesmo tempo, moral - porque ela recoloca a questão do gosto na esfera da origem em que ele se constituiu, fisicamente: aquela do corpo e, mais precisamente ainda, do lugar
} 
do corpo que - por seus orifícios, excreções e odores — coloca mais em jogo o afrontamento do belo e do feio, do nobre e do ignóbil: os órgãos sexuais." (p.27)

Assim, encontramo-nos no registro do corpo e é a esse registro que o quadro de Courbet tanto quanto a instalação de Duchamp nos enviam.

Não é por acaso que o feminino e o corpo tenham estado sempre vinculados, fazendo com que um pensamento sobre o corpo tombe sobre o feminino e vice-versa. A mulher objeto do olhar e da ação dos artistas é o corpo feminino idealizado como expressão do Belo. Mas esse corpo feminino expressão do Belo não pode ser senão um corpo retirado de tudo que o torna carnal, assim como uma mulher retirada de tudo o que a torna feminina. Assim, trata-se de uma subtração, feita a partir do momento em que corpo e feminino são inscritos enquanto lugares de ausência de obra, subtração, consequentemente, de suas condições de obra. E veremos que, na história da arte, é sempre esse corpo de mulher subtraído daquilo que poderia nos enviar quer ao corpo, quer à mulher, o que é posto em cena.

É a partir da filosofia que o homem é dividido em dois: uma alma e um corpo, estando o segundo sempre identificado à natureza, ao feminino, à mortalidade e à decadência do homem. O corpo e o feminino são vinculados por esse discurso e, no campo artístico, vemos frequentemente os impasses e as manobras aos quais os artistas apelam a fim de conceber as representações de mulher e do corpo de tal maneira que seus aspectos mais singulares serão negados na maior parte do tempo.

Nessa disputa entre a ideologia falocrática que mantém a divisão e o esforço de recolocar em cena aquilo que fica negado pela mesma — o feminino e o corpo como retornos do recalcado, eu poderia dizer — é interessante constatar que algumas mudanças mais profundas terão lugar no momento em que as mulheres ingressam no campo artístico, trazendo consigo seus corpos.

Quando falamos de corpo, e de corpo feminino, somos enviados ao campo das pulsões e ao campo das bordas. E chego a afirmar que é nesses campos de borda que a subjetivação tem lugar para se fazer no mundo contemporâneo, tese para a sustentação da qual a referência às artistas contemporâneas e a seus trabalhos me auxiliou muito. Retornemos à arte contemporânea.

Em textos precedentes (RIBEIRO, 2008a, 2008b, 2008c, 2009, 2010a, 2010b) tentei apresentar, a partir do trabalho de três artistas contemporâneas, o que poderia ser considerado como indicação dos lugares possíveis para a subjetivação em nossos tempos, sejam eles o corpo e o feminino.

Assim, apresentei o corpo feminino como tendo sido tomado e representado, no campo da arte, sempre enquanto corpo asséptico em ligação direta com a economia do olhar que, a fim de contemplá-lo, fez e quis ver outra coisa 
que a constatação da castração e da falta. O corpo asséptico da mulher sendo, assim, a negação de tal falta e do feminino propriamente dito, um corpo subtraído de toda sua materialidade enquanto corpo. O corpo subtraído de sua materialidade e de sua feminilidade como encarnação da estratégia de disciplinamento que o dociliza, através da retirada daquilo que, nesse corpo, seria a materialidade de sua resistência à sua sujeição: sua carnalidade e seus atributos femininos.

O que propõe Nazareth Pacheco, a primeira artista sobre a qual escrevi, é uma reintrodução do corpo carnal na obra, que faz frente a tal corpo asséptico da mulher apresentado pela arte, por meio da captura e do aprisionamento que ela faz do olhar entre os brilhos e cortes de seus objetos, alusões a um corpo despedaçado, sangrando, que mesmo em ausência se presentifica através dos materiais e de seu próprio sangue.

Também apresentei o corpo feminino, sempre ligado a essa economia do olhar, enquanto corpo/desvelamento, o feminino guardando a verdade última da castração em seu próprio desnudamento. Feminino enquanto desvelamento aprisionado à lógica da mulher enquanto histérica, feminino patologizado a serviço da sustentação da lógica fálica, que garante a manutenção da ideia de essência e de origem.

O que propõe Cindy Sherman, a segunda artista a respeito da qual escrevi, é colocar em questão a lógica fálica de uma verdade última incluída nessa assunção da mulher como desvelamento, através do apagamento do sujeito em suas obras, o percurso em direção ao vazio e à ausência de figura humana tanto quanto à ausência de origem apresentada por suas obras de máscaras, manequins ou cópias de quadros da história da arte dos quais falta o original.

Por fim, apresentei o corpo desligado do feminino levando à radicalização de sua materialidade fora dessa remissão a uma lógica fálica, na qual a feminilidade ainda estaria parcialmente inscrita, levando ao retorno a uma imobilização perversa enquanto defesa face ao confronto com o último de tal corporeidade que é a morte. O limite absoluto desse corpo mortal promovendo um contorno não mais pautado pela ultrapassagem no próprio corpo, mas pelo deslocamento para o âmbito do imaginário, recuperando a imobilização perversa. Marina Abramovic propõe tanto a presença desse corpo na apresentação de sua carnalidade quase absoluta quanto a possibilidade de sua transcendência/ negação por meio do recurso a um deslocamento imaginário/perverso para além de seus limites.

Cada uma a seu modo, as artistas reenviam seu olhar na direção do espectador, voyeurismo do espectador que é, naquele momento, olhado enquanto olha. É o fim do conforto e da proteção de sua posição. As obras o olham. É também o fim da passividade do feminino que se dá ao olhar do outro. Consiste nesse reenvio do olhar ao espectador e no seu aprisionamento nesse lugar voyeur o 
ponto de partida da estratégia utilizada por essas artistas a fim de recolocar corpo e feminino em jogo, enquanto lugares de borda nos quais se constrói uma possibilidade de subjetivação.

\section{ALGUNS APORTES DAS ARTES VISUAIS PARA A PSICANÁLISE}

O que temos como aporte para a psicanálise, a partir do campo das artes visuais, trazido para esse trabalho especialmente por meio da discussão das produções de Nazareth Pacheco, Cindy Sherman e Marina Abramovic, é que esse paradoxo apresentado por Foucault acerca do saber psicanalítico servindo ao poder disciplinar e seu discurso possibilitando uma brecha de resistência e de transgressão desse mesmo poder é recolocado naquilo que as artistas sugerem ao campo psicanalítico, desde a discussão que fazem a respeito do corpo e do feminino.

Assim, o corpo asséptico do qual partem suas obras, ao aprisionar os espectadores em seus encantos brilhantes e sedutores, de uma mesma sedução — artifício desse corpo transformado e domesticado em máquina de seduzir, a fim de transtorná-lo por meio da reintrodução da materialidade corpórea descartada até então - e não apenas nas produções artísticas, como também em vários campos em que o poder disciplinar agiu sobre esses corpos, as artes espelhando apenas essa estratégia do poder que se abateu sobre eles - e que será levada até sua radicalidade última de carnalidade e finitude, aproxima-se - enquanto movimento - do campo pulsional instituído por Freud no âmbito psicanalítico. Corpo que não se dociliza posto que escapa da submissão total à possibilidade de inscrição psíquica dada pela representação. Corpo que escapa não só graças à existência de um inconsciente que retira o sujeito da razão e da consciência do lugar de controle e de ordenamento sobre si mesmo e, consequentemente, sobre esse corpo mas, principalmente, conforme esse inconsciente seja tão mais marcado pelos movimentos pulsionais que o investem enquanto desejo do que por sua falha condição de abarcá-los.

A brecha do corpo dócil e sua possibilidade de resistência parecem estar naquilo que as artistas apontam como reintrodução desse corpo no âmbito da obra de arte, e que a psicanálise é forçada também a reintroduzir, no momento em que o campo psíquico não dá conta daquilo do sujeito que lhe escapa e Freud se vê obrigado a considerar uma brecha advinda de suas reconsiderações em relação ao pulsional, por meio da introdução da ideia de pulsão de morte, mesmo movimento feito por Lacan em relação ao Real.

No que diz respeito ao feminino, um movimento análogo se faz presente no campo psicanalítico, de uma circunscrição do mesmo à lógica fálica até sua explosão naquilo que Freud (1937/1996) não sabe sobre a mulher e que não se abarca nos meios e modos como ela se constitui a partir da castração. O feminino 
- como o corpo pulsional — retorna como resto e como resistência frente a, e no mesmo lugar em que haviam sido engolidos por essa lógica psicanalítica a serviço de um saber acerca da sexualidade, um saber domesticador.

Aqui, também, a contribuição trazida pelas artistas trabalhadas mostra o movimento que parte desse feminino aprisionado no campo da lógica fálica, na medida em que colocado em equivalência com a mulher histérica do corpo a ser domado, em direção à desconstrução, ponto a ponto, de cada uma de suas imagens, até que não sobre alternativa que não a de perceber a falácia dessa mulher histérica referida à castração enquanto definição acerca do feminino. O que as artistas aportam para a psicanálise, nesse sentido, é a falência da lógica da máscara.

Interessante ressaltar que esses consistem, precisamente, nos pontos de maior alienação do indivíduo — seu corpo e o ser mulher — tais quais propostos por Foucault (1975) enquanto pontos sobre os quais recaem as estratégias de poder como saber, a partir do momento em que tal poder passa a decidir sobre a vida dos homens... É desses pontos de maior alienação e sujeição que surgem as possibilidades de resistência e rebelião, como nos mostraram as produções e os percursos de Nazareth Pacheco, Cindy Sherman e Marina Abramovic, cada qual partindo do corpo e do feminino em alguns dos seus lugares mais cristalizados e, por meio de uma estratégia extremamente interessante, recolocando-os em movimento — eis a resistência — do lugar em que pareciam mais fixos.

Recebido em 12/11/2010. Aprovado em 4/1/2011.

\section{REFERÊNCIASS}

BIRMAN, J. (1999) Cartografias do feminino. São Paulo: 34.

(2006): Arquivos do mal-estar e da resistência. Rio de Janeiro: Civilização Brasileira.

BLANCHOT, M. (2004/1969) L'entretien infini. Paris: Gallimard. FOUCAULT, M. (2002/1964) A loucura, a ausência da obra. Rio de Janeiro: Forense Universitária, p.210-219. (Coleção Ditos e Escritos, v.1) (1972) História da loucura na Idade Clássica. São Paulo: Perspectiva. (1975/1987) Vigiar e punir: história da violência nas prisões. Petrópolis: Vozes.

(1976/1988) História da sexualidade I: a vontade de saber. Rio de Janeiro: Graal. 
FREUD, S. (1996) Edição standard brasileira das obras psicológicas completas de Sigmund Freud. Rio de Janeiro: Imago.

(1893-1895) "Estudos sobre a histeria”, v.II, p.1-350.

(1900) “A interpretação dos sonhos”, vs.IV-V, p.1-735.

(1905) "Três ensaios sobre a teoria da sexualidade", v.VII, p.119-232.

(1914a) "Sobre o narcisismo: Uma introdução", v.XIV, p.77-110.

(1914b) “O Moisés de Michelangelo”, v.XIII, p.213-242.

(1915a) “Os instintos e suas vicissitudes”, v.XIV, p.117-146.

(1915b) "O inconsciente”, v.XIV, p.165-224.

(1923) “O ego e o id”, v.XIX, p.15-82.

(1925[1924]) “Uma nota sobre o bloco mágico”, v. XIX, p.253-262.

(1931) “A sexualidade feminina”, v.XXI, p.231-254.

(1933) "Novas conferências introdutórias à psicanálise - Conferência XXXIII: Feminilidade”, v.XXII, p.113-134.

LACAN, J. (1964) Os quatro conceitos fundamentais da psicanálise. Rio de Janeiro, Jorge Zahar, 1998.

(1972-73) Mais, ainda. Rio de Janeiro: Jorge Zahar, 1985.

MARCADÉ, B. (1995) “Le devenir-femme de l’art”, in Féminimasculin: Le sexe de l'art. Catálogo de exposição homônima ocorrida de 24/10/1995 a 12/2/1996 no Centre Georges Pompidou. Paris: Gallimard/Electra, éditions Du Centre Georges Pompidou.

RIBEIRO, A. M. (2008a) “Ampliações do feminino”, in ALONSO, S.L.; BREYTON, D.M.; ALBUQUERQUE, H. (Org.) Interlocuções sobre o feminino na clínica, na teoria, na cultura. São Paulo: Escuta/Instituto Sedes Sapientiae.

. (2008b) O grotesco, o estranho e a feminilidade na obra de Cindy Sherman. Ide - psicanálise e cultura, n.47. São Paulo: Sociedade Brasileira de Psicanálise de São Paulo, p.88-93.

. (2008c) Cindy Sherman: sobre o feminino. Psyche, n.22. São

Paulo: Unimarco, p.35-54.

. (2009) Nazareth Pacheco e o corpo. Concinnitas, v.1, n.14. Rio de Janeiro: Instituto de Artes da Uerj, p.104-119.

. (2010a) "Da perversão à sublimação: algumas estratégias das artes visuais para a criação de lugares de subjetivação e presença de obra nas bordas do corpo e do feminino”. Tese de doutorado. Programa de Pós-graduação em Teoria Psicanalítica, IP, UFRJ.

(2010b) Le corps et le féminin dans l'art contemporain. Revue Recherches en Psychanalyse, n.9. Disponível em: http://recherchespsychanalyse.revues.org/index797.html. Acesso em 4/11/2010.

Alessandra Monachesi Ribeiro

alemonachesi@gmail.com 